\title{
ON RESEARCH OF ESTONIAN SCHOOL STUDENTS' PHYSICAL DEVELOPMENT IN DIPLOMA THESES OF THE DEPARTMENT OF ZOOLOGY AT TARTU STATE UNIVERSITY, 1958-1970
}

\author{
Part I \\ Tiiu Kasmel, JaAn Kasmel \\ Centre for Physical Anthropology, University of Tartu, Tartu, Estonia
}

\begin{abstract}
The article provides an overview of ten diploma theses written under the supervision of Professor of Zoology Juhan Aul at the University of Tartu from 1958-1970. The theses deal with physical development of Estonian school students in two Estonian towns (Tartu and Pärnu) and nine districts (Tartu, Elva, Põlva, Räpina, Rapla, Keila, Pärnu, Võru, Harju) according to the then existing administrative division. The theses are based on the anthropological material collected from 1956-1966.

The first part of the article briefly describes the period of nearly 202 years during which the scholars related to the University of Tartu have conducted various physical anthropological studies on Estonians. These years can conditionally be divided as follows: the first period, 1814-1927 - the period from Baer to Aul, the second period, 1927-1993 - the Aul period, the third period, from 1993 to the present - the period of the Centre for Physical Anthropology.

The article describes some of the options the students had for participating in anthropological research. An overview is given of the beginning of anthropological research of children and school students in Estonia and in the world. The article acquaints the reader with the whole of the so-called Aul period and the diploma theses on Estonian school students' physical development supervised by him.
\end{abstract}

The second part gives an overview of the diploma theses.

Keywords: history of anthropology; Karl Ernst von Baer; Juhan Aul; University of Tartu 
For more than two centuries, during the 202 years that are fulfilled in September this year, researchers related to the University of Tartu have conducted various physical anthropological studies on Estonian men, women and children (school students).

This time span can conditionally be divided into three periods.

The first period of Estonians' anthropological research began with the defence of Karl Ernst von Baer's doctoral thesis in 1814 [22] and lasted until the 1930s. Then, after the end of World War I and proclamation of independence of the Republic of Estonia (1918), the results of the first extensive anthropological studies were published and, from 1927, systematic anthropological research began, its pioneer being Professor of Zoology Juhan Aul (1897-1994) [13]. This first period (1814-1927) might be called from Baer to Aul.

The second period of Estonians' anthropological research can mainly be associated with J. Aul until 1993 when the Centre for Physical Anthropology was founded during the reforms at the University of Tartu after the Republic of Estonia had regained its independence in 1991. This period (1927-1993) could be called the Aul period.

It could additionally be said about the beginning of the third period of Estonians' anthropological research that, in the final years of the so-called Aul period, a research group interested in Estonians' anthropological research had gathered around Prof. Helje Kaarma (1933) at the Department of Obstetrics and Gynecology at the University of Tartu. At the initiative of Prof. Kaarma and with the support of Prof. Peeter Tulviste (1945), then Rector of the University of Tartu, the Centre for Physical Anthropology was founded at the Institute of Anatomy of the Faculty of Medicine. The Centre has been operating until the present [8].

Throughout times, students of different specialities at the University, supervised by the teaching staff, have conducted research in many areas, including anthropology.

Nowadays, they present their research results as term papers, Bachelor's and Master's theses.

More than a quarter of a century ago, before 1991, the students of the Soviet university had to present their studies as either term papers or diploma theses.

Students could also participate in the activities of Students' Research Society (founded in 1948), which consisted of groups according to specialities. In some years, those covered all the specialities taught at the university. At annual conferences of the Society, the authors of the best student papers made oral presentations on their research. The research results could be submitted as prize essays [17]. 
Anthropology was also represented among both oral presentations and prize essays.

Below, we will discuss only the diploma theses dealing with the physical development of Estonian school students, which were written at the Department of Zoology of Tartu State University from 1958-1970 [12].

The diploma thesis was a student's independent research paper that had to be defended before the national examination board in order to complete one's studies at the university [5].

Writing diploma theses on anthropology became possible, as studies of Estonian school students' physical development were included in the research plan of the Department of Zoology of Tartu State University from 1956.

Research was supervised by J. Aul who worked at the Department as halftime Associate Professor. He involved biology students as assistants in collection of anthropological material from different regions of Estonia, which lasted until 1966 [12].

Later, the students could participate in analysing and summarising the collected material, using the measuring results to present overviews of the physical development of school students of one or another region in their term papers or diploma theses. The writing of the latter was supervised by Prof. J. Aul [13].

It is difficult to establish when the anthropological research of children and school students of one or another nation began

The first reports on anthropological characteristics of ethnic Estonian school students date back to the last quarter of the $19^{\text {th }}$ century. In 1888 , Ch. Ströhmberg, school doctor of Alexander Gymnasium in Dorpat (now Tartu) published data on height and chest circumference of 465 boys (aged 10-21 years) of his school. As names were recorded, it is possible, within a small margin of error, to find ethnic Estonian schoolboys and to get a more or less truthful overview of the development of Estonian schoolboys' body height and chest circumference at that time [4].

In 1922, Tartu school doctor Hans Madisson (1887-1955) published an article that already included the data of a large sample of Tartu school students' height and body mass ( 905 boys and 562 girls aged 7-17 years) [2]. These should be the first published data on Estonian school students' body mass.

Concerning the beginning of children's (school students') anthropological measuring in general, the following could be said.

The first measurements of children in the world were most probably conducted by G. L. L. de Buffon in the $18^{\text {th }}$ century. 
The first serial measurements of children are associated with the name of Ketle in the 1830s.

Massive research of school students' physical development began in the middle of the second half of the $19^{\text {th }}$ century [4].

Before dealing with diploma theses supervised by J. Aul on Estonian school students' physical development, we present a short overview of his life and work in order to show the level of the anthropologist who supervised of these papers.

At the beginning of the current study, we conditionally divided the whole time of Estonians' anthropological research at the University of Tartu, nearly 202 years, into three periods, and called 1927-1993 the Aul period. Its overview is given below.

The whole so-called Aul period in Estonian men's, women's and children's (school students') anthropological research can be divided into three parts:

1) 1927-1941 - the first period of Aul's anthropological studies of Estonians:

In summer 1927 he began anthropological studies of Estonians on Sõrve peninsula; in the following years, he gave a broader basis to those studies.

From 1932, he broadened his studies to get an anthropological overview of the whole of Estonia [12].

From 1932-1936, he measured nearly 15,000 men of approximately the same age who were released from military service. The conclusions were published in 1964 in the monograph Антропология эстонцев (Anthropology of Estonian Men) [21].

From 1932-1940, he measured more than 2000 school students aged 12-19 years. An overview was published in the article "Eesti kooliõpilaste füüsilisest arengust aastail 1932-1940" (On Estonian school students' physical development, 1932-1940) [2].

On 19 March 1939, he was awarded the degree of Doctor of Natural Sciences for his thesis Lääne-Eesti maakondade eestlaste antropoloogilisi tunnuseid ja tõuline kuuluvus (Anthropological Features and Racial Affiliation of Estonians in the Counties of West Estonia).

From 1 August 1938 to 1 April 1939, he was on an anthropological research trip to Poland, Germany and Switzerland.

On 27 April 1939, he founded the Anthropology Section of the Estonian Naturalists' Society.

On 31 May 1939, he delivered his habilitation lecture "Antropoloogiliste tunnuste vanuseliste muudatuste metodoloogilisest tähtsusest" (On the methodological significance of age-related changes in anthropological features). 
On 3 October1939, the University of Tartu Council awarded him the rank and rights of Associate Professor in Anthropology [12].

2) 1941-1954 - the second period of Aul's anthropological studies of Estonians. This was the period when anthropological research was hindered or interrupted. This period can, in its turn, be divided into three parts:

a) the war years 1941-1944:

During the battles that devastated Tartu in 1941, J. Aul contributed greatly to preservation of the university building at 46 Vanemuise Street and salvage of the property. As superintendent of the building, he put out the flames on the roof of the annex and, with a few helpers, fully extinguished the fire [12].

His diligent work had made Estonia the anthropologically most thoroughly researched country, as can be seen in an interview with J. Aul in the newspaper Eesti Sõna in December 1942 [6].

b) the post-war years 1944-1950:

On 10 November 1944, J. Aul was appointed to the position of Senior Lecturer at the Department of Zoology.

On 1 September 1946, he was appointed Acting Associate Professor of the same Department.

On 7 February 1948, his degree of Doctor of Biology and title of Associate Professor were confirmed [12].

In 1949, Karin Mark (1922-1999) defended her diploma thesis Paleoantropoloogilisi andmeid Eesti NSV ja selle idapoolsete piirialade noorema rauaaja kohta (Palaeoanthropological Data on Early Iron Age in the Estonian SSR and its Eastern Bordering Areas).

In 1950, M. Ilves defended the diploma thesis Ahja jõe ümbruse mammaalidefauna (Mammal Fauna of the Surroundings of the Ahja River, 53 pp.) and E. Kiisel Oravhiire ökoloogiast (On the Ecology of the Garden Dormouse, 29 pp.) [12].

The supervisor of these three diploma theses was Assoc. Prof. J. Aul; the first of them was the very first diploma thesis supervised by him.

c) 1950-1954, for a few days more than 4 years and 1 month, J. Aul was excluded from work at the university as "not meeting the requirements of the university" and as a "bourgeois nationalist" [12].

Nonetheless, the Great Soviet Encyclopaedia published an overview of J. Aul's work on p. 481 in the $3^{\text {rd }}$ volume of its $2^{\text {nd }}$ edition (1950) [22].

During this time, from 1950-1954 not a single publication by J. Aul appeared.

The following two events could have an inspiring influence on Estonian anthropology and J. Aul. 
From 1952-1954, the USSR Academy of Sciences organised a combined expedition in the Baltics (Estonia, Latvia, Lithuania) and their neighbouring areas in the Russian Federation and Belarus. This also included anthropological research of the population of those areas simultaneously and following the same methodology. In conclusion, a conference was held in Vilnius in 1955; the materials of the expedition were published in two volumes [11].

From 14 January to 5 April 1954, E. Närska from the Hygiene Sector of Tallinn Research Institute of Epidemiology, Microbiology and Hygiene conducted a study of physical development of students of eight secondary schools in Tallinn (2491 students were measured). The results of the study, including standard tables for assessment of physical development of Estonian school students, were published in Issue 5 of the journal Nõukogude Eesti Tervishoid (Soviet Estonian Health Care) in 1956 [11].

3) from autumn 1954 to 1993 - the third period of Aul's anthropological studies.

From 20 September 1954, J. Aul was restored to the post of half-time Associate Professor at the Department of Zoology.

On 9 January 1957, the USSR Higher Attestation Commission gave J. Aul the academic rank of Professor of Zoology.

In 1958, after Prof. H. Riikoja's retirement, J. Aul was elected Head of the Department of Zoology. He occupied this post until 1 September 1969, after which he continued working at the Department as Professor.

From 1 September 1976 to 15 October 1982, he was Consulting Professor of the Department of Zoology [12].

To gain a better understanding of the so-called Aul period (1927-1993), of the first and partially the second period of Estonians' anthropological studies (1927-1944), we present his main places of employment in these years, which provided him with income and enabled him to deal with anthropology.

In the autumn of 1921, J. Aul entered the Faculty of Mathematics and Natural Sciences at the University of Tartu to study zoology. During his studies, in order to earn his living and to pay for the tuition at the university, he worked as a teacher at Tartu Evening Primary School and Teacher' Seminary, and as a lecturer at the Folk High School of the Education Union. Along with that, as still a student, he laid the foundation to systematic anthropological study of Estonians in summer 1927.

In 1928, J. Aul graduated from the university with a Master's degree in zoology and continued working at the Institute of Zoology as Acting Junior Assistant. As of 1 January 1929, he became Senior Assistant, for the time being also continuing to work as a teacher. 
From 1940 to his retirement in 1982, J. Aul lectured on anthropology at the university, at first to the students of zoology, finally, only at the Department of Psychology [12].

As of 6 August 1940, the Republic of Estonia became one of the union republics of the Soviet Union. The University of Tartu also became a Soviet institution of higher education, known by the name of Tartu State University. The names of its structural units were also changed; the Institute of Zoology became the Department of Zoology, and on 30 May 1941, J. Aul was appointed its Acting Senior Lecturer.

On 1 June 1941, he was appointed to the post of Head of Zoology Sector at the Scientific Research Institute of the Estonian SSR.

The University of Tartu could not be evacuated after the breakout of the war between Germany and the Soviet Union on 22 June 1941.

During the following German occupation (from 18 July 1941 to 18 September 1944), Aul continued working at the university. The former names of the university and its structural units were restored, and Aul worked as Associate Professor at the Institute of Zoology [12, 17].

J. Aul's preparations for creating a professorship of anthropology at the university and his project for opening an institute of anthropological research at the Estonian Academy of Sciences were interrupted by the war [12].

Even before J. Aul started studying Estonian school students' physical development in 1956, he had managed to collect, during the very difficult last 20 years, the major part of the material from eight regions for his study Estonian Women's Anthropology, which was published in 1977 by Professor J. Aul's $80^{\text {th }}$ birthday [3].

Professor Juhan Aul's list of bibliography from 1919-1997 (1997) presents the titles of all the 21 diploma theses supervised by him from 1949-1976. Ten among them, written from 1958-1970, deal with physical development of Estonian school students in two Estonian towns (Tartu and Pärnu) and nine districts according to the then existing administrative division (Tartu, Elva, Põlva, Räpina, Rapla, Keila, Pärnu, Võru, Harju) [12].

The bibliography of diploma theses of the Department of Zoology from 1949-1986 (1986) shows that a total of 80 diploma theses were defended at the Department in the years under discussion, i.e. 1958-1970. They were supervised by 20 persons, four of them were from the Faculty of Medicine. A diploma thesis on ornithology, defended in 1970, had two supervisors [15]. 
J. Aul and his assistants (students) started collecting material for studying the physical development of 7-18-year-old Estonian school students in the town of Tartu. The studies were conducted in 1956 and 1957; a total of 2906 students were researched, among them 1512 girls 1394 boys [14].

In Tartu and Elva districts, the measurements were conducted in three years, from 1956-1958; a total of 2480 students were researched, among them 1265 girls 1215 boys [10].

In Põlva and Räpina districts, the measurements were conducted in 1958; a total of 2293 students were studied, among them 1183 girls 1110 boys [19].

In Rapla district, the studies were conducted in 1960; a total of 2091 students were studied, among them 1069 girls 1022 boys [7].

In the town of Pärnu, the measurements were conducted in two years, 19591960, a total of 1874 students were measured - 936 girls and 938 boys [16].

In Keila district, the measurements were conducted in two years, 1961-1962, a total of 1680 students were measured - 838 girls and 850 boys [18].

In Pärnu district, the studies were conducted in 1962; a total of 2355 students were measured, among them 1221 girls 1134 boys [13].

In South Estonia (Võru district), the measurements were conducted in 1966; 1292 girls were measured. The number of boys measured is not known, but based on the analysis of data, a term paper was written in 1968 [9].

In Harju district, the studies were conducted in 1961; a total of 2109 students were measured, among them 1064 girls 1045 boys [1].

The measurements were conducted in schools of different districts in September of the above-mentioned years. The measurements were taken by J. Aul in person to avoid the differences which are inevitable when several persons carry out the measuring.

The measurements were conducted according to the generally known rules of R. Martin and with instruments taken into use by him [7].

Below, we present, in the order of their years of defence, the title pages of ten diploma theses written in 1958-1970 for studying Estonian school students' physical development.

For each diploma thesis, we present its title in English, its place and year of defence, number of pages, amount of literature used, and materials presented in appendices. 


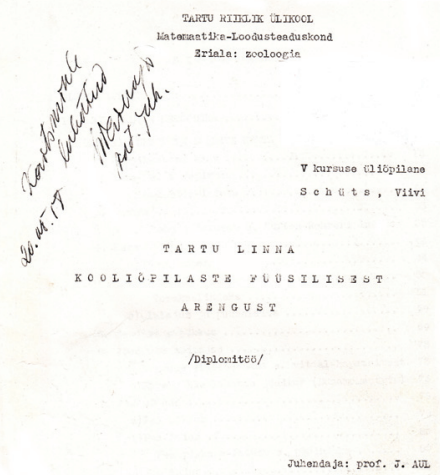

Tartu 1956

Figure 1. Schüts, Viivi. On Physical

Development of School Students of the Town of Tartu.

Tartu, 1958, 94 pp.

Bibliography - 14 items.

Appendix: Tables on 12 pages (42-65).

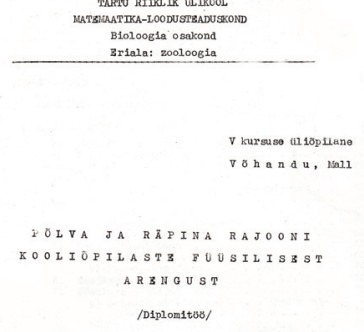

Tartu 1961

Figure 3. Võhandu, Mall. On Physical Development of School Students of Põlva and Räpina Districts.

Tartu, 1961, $126 \mathrm{pp}$.

Bibliography - 20 items.

Appendix: Tables on 11 pages (1-22).

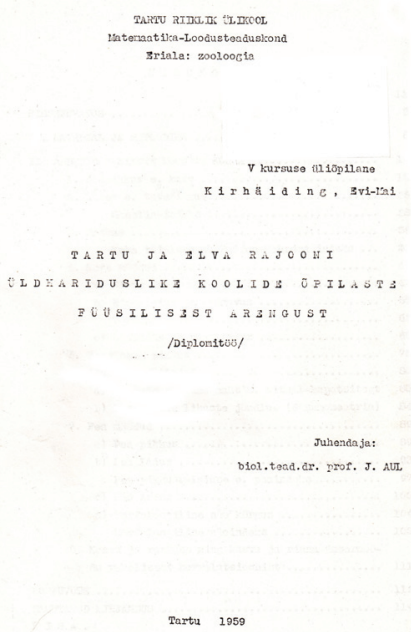

Figure 2. Kirhäiding, Evi-Mai. On Physical Development of Students in Schools of General Education in the Districts of Elva and Tartu.

Tartu, 1959, $116 \mathrm{pp}$.

Bibliography - 21 items.

Appendix: Tables on 12 pages (65-88).

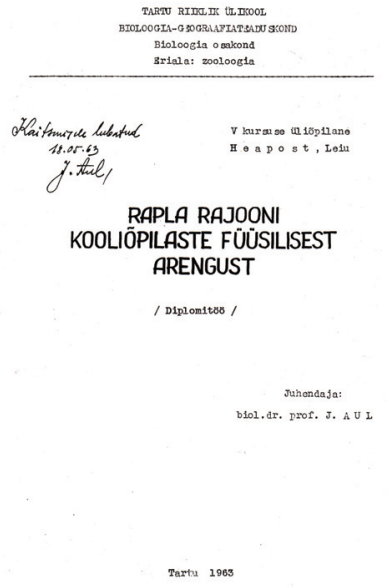

Figure 4. Heapost, Leiu. On Physical Development of School Students of Rapla District.

Tartu, 1963, 141 pp.

Bibliography - 35 items.

Appendix: Tables on 12 pages (1-24). 


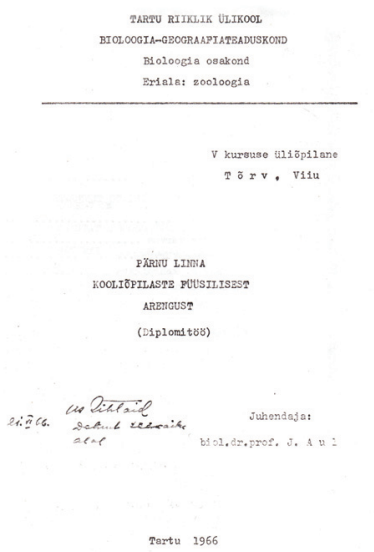

Figure 5. Tõrv, Viiu. On Physical

Development of School Students of the Town of Pärnu.

Tartu, 1966, 146 pp.

Bibliography - 34 items.

Appendix: Tables on 11 pages (80-101); summary in Russian on 3 pages.

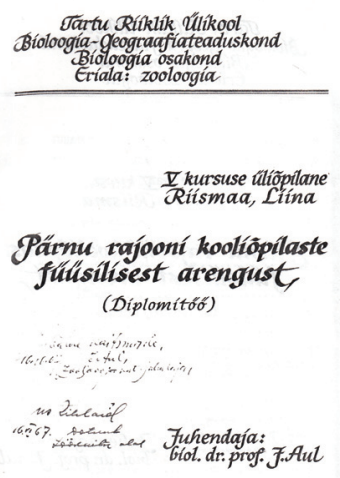

Jartu 1967

Figure 7. Riismaa, Liina. On Physical Development of School Students of Pärnu District.Tartu, 1967, 129 pp.

Bibliography - 31 items.

Appendix: Tables on 11 pages (71-92); anthropological observation sheet, form no. 3; summary in Russian on 3 pages.

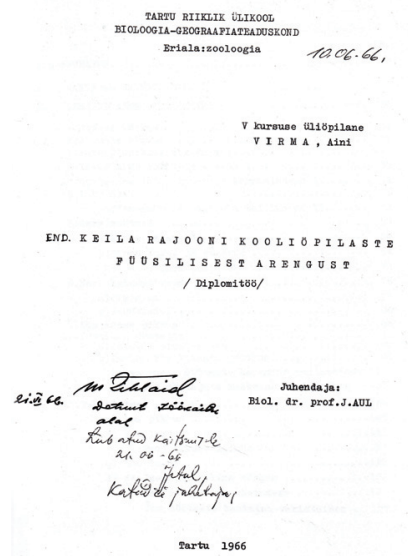

Figure 6. Virma, Aini. On Physical Development of School Students of the Former Keila District.

Tartu, 1966, $139 \mathrm{pp}$.

Bibliography - 37 items.

Appendix: Tables on 12 pages (1-24); summary in Russian on 2 pages.

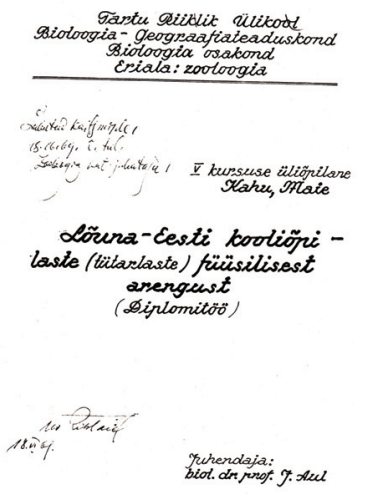

Saste 1960

Figure 8. Kahu, Maie. On Physical Development of South Estonian School Students (Girls).

Tartu, 1969, 111 pp.

Bibliography - 26 items.

Appendix: Tables on 4 pages (1-4). 


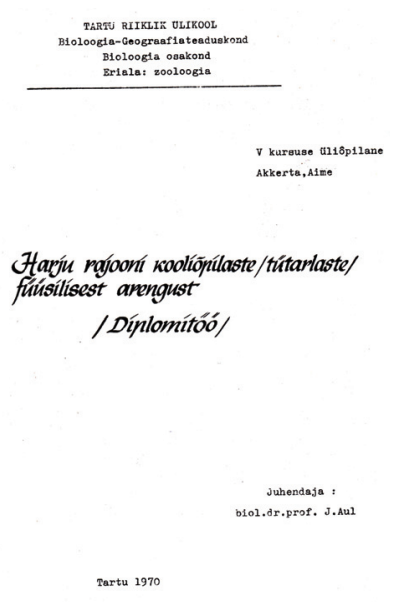

Figure 9. Akkerta, Aime. On Physical Development of School Students (Girls) of Harju District.

Tartu, 1970, $123 \mathrm{pp}$.

Bibliography - 36 items.

Appendix: Tables on 4 pages (1-4); anthropological observation sheet, form no. 3; summary in Russian on 3 pages.

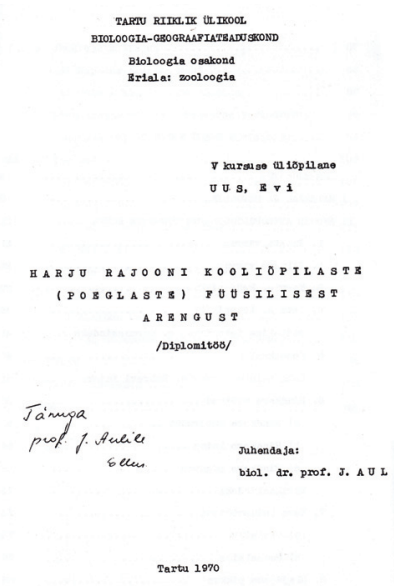

Figure 10. Uus, Evi. On Physical Development of School Students (Boys) of Harju District.

Tartu, 1970, $141 \mathrm{pp}$.

Bibliography - 37 items.

Appendix: Tables on 4 pages (1-4); anthropological observation sheet, form no. 3; summary in Russian on 2 pages.

An overview of these diploma theses will be presented in the next issue of Papers on Anthropology.

\section{REFERENCES}

1. Akkerta A. (1970). Harju rajooni kooliõpilaste (tütarlaste) füüsilisest arengust. Tartu.

2. Aul J. (1973). Eesti kooliõpilaste füüsilisest arengust aastail 1932-1940. Loodusuurijate Seltsi Aastaraamat, 62, 191-222.

3. Aul J. (1977). Eesti naiste antropoloogia. Tartu Riikliku Ülikooli Toimetised. Vihik 438. Tartu.

4. Aul J. (1982). Eesti kooliõpilaste antropoloogia. Tallinn.

5. Diplomitöö (1987). Eesti Nõukogude Entsüklopeedia. Tallinn: Valgus, 2, 128.

6. Eesti on antropoloogiliselt paremini uuritud maa maailmas. Jutuajamine $d r$. phil. nat. J. Auliga (1942). Eesti Sõna, 2.12, 278, 4.

7. Heapost L. (1963). Rapla rajooni kooliõpilaste füüsilisest arengust. Tartu.

8. Kaarma H. (2013). Twenty years of the Centre for Physical Anthropology. Papers on Anthropology, XXII, 11-16. 
9. Kahu M. (1969). Lõuna-Eesti kooliõpilaste (tütarlaste) füüsilisest arengust. Tartu.

10. Kirhäiding E.-M. (1959). Tartu ja Elva rajooni üldhariduslike koolide õpilaste füüsilisest arengust. Tartu.

11. Närska E. (1956). Tallinna kooliõpilaste füüsilise areng. Nõukogude Eesti Tervishoid, 5, 107-117.

12. Professor Juhan Aul. Kirjanduse nimestik 1919-1997 (1997). Tartu.

13. Riismaa L. (1967). Pärnu rajooni kooliõpilaste füüsilisest arengust. Tartu.

14. Schüts V. (1958). Tartu linna kooliõpilaste füüsilisest arengust. Tartu.

15. Zooloogia kateedri diplomitööde bibliograafia 1949-1986 (1986). Tartu.

16. Tõrv V. (1966). Pärnu linna kooliõpilaste füüsilisest arengust. Tartu.

17. Universitas Tartuensis 1632-2007 (2007). Tartu.

18. Virma A. (1966). End. Keila rajooni kooliõpilaste füüsilisest arengust. Tartu.

19. Võhandu M. (1961). Põlva ja Räpina rajooni kooliõpilaste füüsilisest arengust. Tartu.

20. Uus E. (1970). Harju rajooni kooliõpilaste (poeglaste) füüsilisest arengust. Tartu.

21. Ауль Ю. [Aul' Ju.] (1964). Антропология эстонцев [Antropologija èstoncev]. (Anthropologia estonica). Tartu Riikliku Ülikooli Toimetised. Vihik 158. Tartu.

22. Ауль Юхан Михкелевич [Aul' Jukhan Mikhkelevič] (1950). Большая советская энциклопедия [Bol’šaja soveckaja ènciklopedija]. $2^{\text {nd }}$ ed., III, 481.

\section{Address for corrrespondence:}

Jaan Kasmel

Centre for Physical Anthropology

University of Tartu

Lossi 38, 51003, Tartu, Estonia / Struve 2, 51003, Tartu, Estonia

E-mail: jaanjkasmel@hot.ee 